\title{
Takao Kashiwagi, Balzac, romancier du regard
}

\section{Marco Stupazzoni}

\section{(2) OpenEdition}

\section{Journals}

\section{Edizione digitale}

URL: https://journals.openedition.org/studifrancesi/40892

DOI: 10.4000/studifrancesi.40892

ISSN: 2421-5856

\section{Editore}

Rosenberg \& Sellier

\section{Edizione cartacea}

Data di pubblicazione: 1 juillet 2004

Paginazione: 207

ISSN: 0039-2944

\section{Notizia bibliografica digitale}

Marco Stupazzoni, «Takao Kashiwagi, Balzac, romancier du regard», Studi Francesi [Online], 142 (XLVIII

I) | 2004, online dal 30 novembre 2015, consultato il 09 septembre 2021. URL: http://

journals.openedition.org/studifrancesi/40892 ; DOl: https://doi.org/10.4000/studifrancesi.40892

\section{Questo documento è stato generato automaticamente il 9 septembre 2021.}

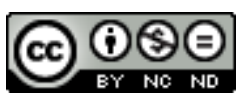

Studi Francesi è distribuita con Licenza Creative Commons Attribuzione - Non commerciale - Non opere derivate 4.0 Internazionale. 


\title{
Takao Kashiwagi, Balzac, romancier du regard
}

\author{
Marco Stupazzoni
}

\section{NOTIZIA}

TAKAO KASHIWAGI, Balzac, romancier du regard, Paris, Librairie Nizet, 2002, pp. 167.

1 Il volume si compone di dodici capitoli, la maggior parte dei quali ripropone saggi e interventi già editi su rivista in tempi diversi.

2 L'A. mostra il ruolo fondamentale dello sguardo e delle molteplici forme della percezione visiva nello svolgersi narrativo di alcuni romanzi della Comédie humaine. In Facino Cane, si stabilisce una stretta connessione tra il protagonista e il narratore sulla base dell'esercizio delle facoltà e delle potenzialità insite nel dono della «seconde vue». Il valore della seconda vista assume un significato fortemente simbolico: «l'unique désir de s'emparer de l'or se concentre sur la vue et la seconde vue emerge de la volonté de combler le fossé entre ce désir et une réalité définie» (p. 11).

Nella scena del primo incontro tra Félix et Mme de Mortsauf descritta nel Lys dans la vallée, lo sguardo riveste un ruolo determinante in relazione alle dinamiche proprie della sensualità e del desiderio e alla dialettica tra sacro e profano.

4 Nei capitoli seguenti, l'A. esamina il significato della percezione visiva verso la metropoli (verticale e orizzontale) di alcuni eroi balzachiani (Rastignac e Rubempré) nel loro itinerario formativo parigino, per poi considerare più da vicino altri testi della Comédie, quali Le Bal de Sceaux e Albert Savarus. In quest'ultima opera, in particolare, la struttura romanzesca 'en abyme' «est établie non seulement dans le système de la nouvelle dans le roman, mais aussi du point de vue du lecteur aussi bien que de celui du protagoniste» (p. 104).

5 Nei due successivi interventi, l'attenzione di Kashiwagi si focalizza sul Chef-d'œuvre inconnu e sulla sua poliedrica funzionalità semantica e ideologica. 
6 I capitoli finali su Balzac e Daumier e sulla fortuna dell'opera di Balzac in Giappone chiudono le pagine del volume.

7 Ci sia consentito, in conclusione, un'ultima riflessione: questa nuova pubblicazione centrata su un tema così suggestivo e così radicato nella scrittura narrativa di Balzac non avrebbe forse dovuto consentire al lettore di apprezzare meglio, grazie ad una riflessione critica organica di più ampio respiro, gli elementi di continuità (o di discontinuità) formale, tematica e strutturale nella rappresentazione di un topos così intimamente legato (fin dai Premiers romans) alla sensibilità umana e letteraria di Balzac, quale appunto la poetica dello sguardo? 